\title{
Pengembangan bahan ajar interaktif pada matapelajaran sistem komputer berbasis PBL untuk SMK
}

\author{
Arizia Aulia Aziiza ${ }^{1}$, Syaad Patmanthara ${ }^{2}$, Triyanna Widiyaningtyas ${ }^{3}$ \\ 1. Universitas Negeri Malang, Indonesia | icha.rizia@gmail.com \\ 2. Universitas Negeri Malang, Indonesia | syaad.ft@um.ac.id \\ 3. Universitas Negeri Malang, Indonesia | triyannaw@gmail.com
}

\begin{abstract}
Abstrak
Berdasarkan hasil wawancara dengan guru matapelajaran sistem komputer kelas $\mathrm{X}$ di SMK Negeri 1 Banyuwangi, bahan ajar yang digunakan masih berupa file dengan format .pdf dari guru dan bersumber dari internet. Bahan ajar yang sesuai dengan kurikulum 2013 revisi masih belum tersedia mengakibatkan siswa kesulitan untuk belajar secara mandiri maupun kelompok, sehingga siswa kurang aktif dalam proses pembelajaran. Bahan ajar berupa buku digital yang dikembangkan terintegrasi dengan model pembelajaran problem based learning (PBL) yang diharapkan mampu mengajak siswa aktif dalam belajar secara mandiri maupun kelompok diskusi untuk menyelesaikan suatu permasalahan. Proses pembelajaran masih menggunakan metode ceramah dengan penyampaian materi menggunakan power point. Metode pengembangan yang digunakan adalah ADDIE (Analysis, Design. Development, Implementation, and Evaluation). Model pengembangan ini meliputi 5 langkah, yaitu: (1) analisis, (2) desain, (3) pengembangan, (4) implementasi, dan (5) evaluasi. Sebelum bahan ajar diimplementasikan, dilakukan validasi dan uji coba untuk mengetahui kelayakan bahan ajar berupa buku digital ini. Hasil validasi dari ahli materi memperoleh persentase validasi sebesar $92.1 \%$ sedangkan ahli media sebesar $86.05 \%$. Uji coba dilakukan sebanyak 3 tahap, yaitu: (1) uji coba perseorangan memperoleh hasil sebesar $77 \%$, (2) uji coba kelompok kecil memperoleh hasil sebesar $81.1 \%$, dan (3) uji coba kelompok besar memperoleh hasil $88.3 \%$.
\end{abstract}

\section{Kata Kunci}

Bahan Ajar Interaktif, Buku Digital, Sistem Komputer, Problem Based Learning.

TEKNO Vol.28 Issue 2, p166-176 | Jurusan Teknik Elektro, Universitas Negeri Malang, Indonesia | September 2018 Arizia Aulia Aziiza, Syaad Patmanthara, Triyanna Widiyaningtyas | Pengembangan bahan ajar interaktif pada judul... 


\section{TEKNO Jumal Teknologi, Eektro, dan kejivuan}

http://journal2.um.ac.id/index.php/tekno | ISSN

\section{Pendahuluan}

Berdasarkan hasil observasi yang dilakukan di SMK Negeri 1 Banyuwangi bahan ajar yang digunakan pada matapelajaran sistem komputer kelas $\mathrm{X}$ berupa hardfile dan softfile, serta bersumber dari internet. Sumber materi dari internet sangat beragam akan mempengaruhi tingkat pemahaman siswa. Tingkat pemahaman siswa mempengaruhi hasil belajar masing-masing siswa. Selain itu, siswa bergantung dan menunggu bahan ajar yang diberikan oleh guru pada setiap pertemuannya, sehingga pada pertemuan selanjutnya siswa belum mempunyai bahan ajar untuk diperlajari. Bahan ajar yang disajikan juga belum menerapkan kaidah penulisan bahan ajar yang benar (Sukmadinata, 2015).

Bahan ajar adalah segala bentuk konten baik teks, audio, foto, video, animasi, dan lain-lain yang dapat digunakan untuk belajar (Tasri et al, 2011). Pada matapelajaran sistem komputer ini, belum memiliki bahan ajar yang lengkap dan terstruktur.

Bahan ajar yang menarik dapat di wujudkan dengan bahan ajar interaktif yang dapat membuat siswa tertarik untuk belajar secara mandiri. Bahan ajar interaktif merupakan paket belajar mandiri yang meliputi serangkaian pengalaman belajar yang direncanakan dan dirancang secara sistematis untuk membantu peserta didik mencapai tujuan belajar (Prihantana et al, 2014).

Tujuan dirancangnya bahan ajar interaktif yang dirancang ini agar siswa memiliki beberapa latihan yang dapat menunjang pemahaman materi dan meningkatkan hasil ulangan mereka. .

Selain bahan ajar, model pembelajaran yang digunakan oleh guru merupakan hal yang sangat penting. Model pembelajaran yang sesuai adalah Problem Based Learning (PBL). pembelajaran berbasis masalah merupakan sebuah pendekatan pembelajaran yang menyajikan masalah kontekstual sehingga merangsang peserta didik untuk belajar (Daryanto, 2014).

Berdasarkan latar belakang yang telah diuraikan, penelitian ini mengembangkan bahan ajar interaktif dengan menggunakan model pembelajaran problem based learning dan memenuhi kebutuhan materi yang sesuai dengan kurikulum. Bahan ajar interaktif berupa buku digital nantinya dapat digunakan guru dan siswa dalam proses pembelajaran yang memudahkan siswa dalam proses pemahaman materi karena penyajiannya materi menggunakan media pembelajan yang tepat sebagai sarana penunjang kegiatan pembelajaran.

\section{Metode}

Penelitian ini bertujuan untuk mengembangkan sebuah produk, yaitu bahan ajar interaktif berupa buku digital pada mata pelajaran sistem komputer dengan menerapkan model pembelajaran Project Based Learning. Penelitian pengembangan ini menggunakan model pengembangan ADDIE (Analysis, Design, Development, Implementation, and evaluation). Model ADDIE dikembangkan oleh Dick and Carry (1996) untuk merancang sistem pembelajaran (Patmanthara, 2014). Berikut adalah diagram alir model pengembangan ADDIE yang memiliki 5 tahapan pengembangan yaitu: (1) Analyze; (2) Design; (3) Development; (4) Implementation; (5) Implementation yang ditunjukkan pada Gambar 1.

TEKNO Vol.28 Issue 2, p166-176 | Jurusan Teknik Elektro, Universitas Negeri Malang, Indonesia | September 2018

Arizia Aulia Aziiza, Syaad Patmanthara, Triyanna Widiyaningtyas | Pengembangan bahan ajar interaktif pada judul... 


\section{TEKNO Jurnal Teknologi, Elektro, dan Kejuruan}

http://journal2.um.ac.id/index.php/tekno | ISSN

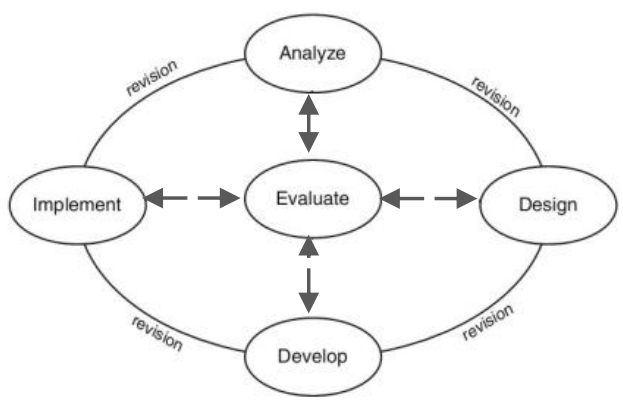

Gambar 1. Model Pengembangan ADDIE (Sumber: Branch, 2009)

Alasan memilih model pengembangan ADDIE ini karena sifatnya yang sederhana, dan sesuai untuk mengembangankan bahan ajar interaktif ini. Selain itu, dalam model pengembangan ADDIE terdapat evaluasi di setiap tahapannya, sehingga memberikan kesempatan pengembang untuk melakukan revisi sebelum bahan ajar digunakan oleh peserta didik secara masal. Berikut adalah prosedur pengembangan ADDIE:

\section{Analisis (Analyze)}

Tahap analisis merupakan tahap awal yang harus dilakukan. Dalam tahap analisis ada beberapa proses yang dilakukan, yaitu: (a) analisis kerja, (b) analisis kebutuhan, (c) analisis materi pembelajaran.

Analisis kinerja dilakukan dengan cara observasi dan wawancara kepada guru dan siswa di SMK Negeri 1 Banyuwangi. Tujuan dilakukannya observasi dan wawancara adalah untuk mengetahui permasalahan apa yang dihadapi oleh siswa maupun guru pada saat proses pembelajaran matapelajaran sistem komputer.

Analisis kebutuhan dilakukan untuk mengetahui kebutuhan siswa dan guru dalam proses pembelajaran matapelajaran sistem komputer. Analisis kebutuhan dilakukan untuk mengetahui model pembelajaran yang sesuai untuk diterapkan dan bahan ajar yang sesuai dengan kurikulum yang digunakan.

Analisis materi pembelajaran disusun berdasarkan Kompetensi Dasar matapelajaran Sistem Komputer kelas $X$ semester 2 . Analisis ini bertujuan sebagai panduan dalam penyusunan materi pada bahan ajar yang dikembangkan.

\section{Desain (Design)}

Desain pengembangan bahan ajar interaktif ini disajikan dalam bentuk buku digital dengan menerapkan model pembelajaran problem based learning.

Desain materi pembelajaran disusun berdasarkan analisis desain materi pembelajaran yang sudah disesuaikan dengan silabus dan KI KD kurikulum 2013 revisi. Penentuan materi pembelajaran problem based learning. Diagram alir dibuat agar mempermudah dalam pengembangan bahan ajar dan menentukan alur dari penggunaan bahan ajar. Struktur diagram alir terlihat pada Gambar 2.

TEKNO Vol.28 Issue 2, p166-176 | Jurusan Teknik Elektro, Universitas Negeri Malang, Indonesia | September 2018 Arizia Aulia Aziiza, Syaad Patmanthara, Triyanna Widiyaningtyas | Pengembangan bahan ajar interaktif pada judul... 


\section{TEKNO Jurnal Teknologi, Elektro, dan Kejuruan}

http://journal2.um.ac.id/index.php/tekno | ISSN

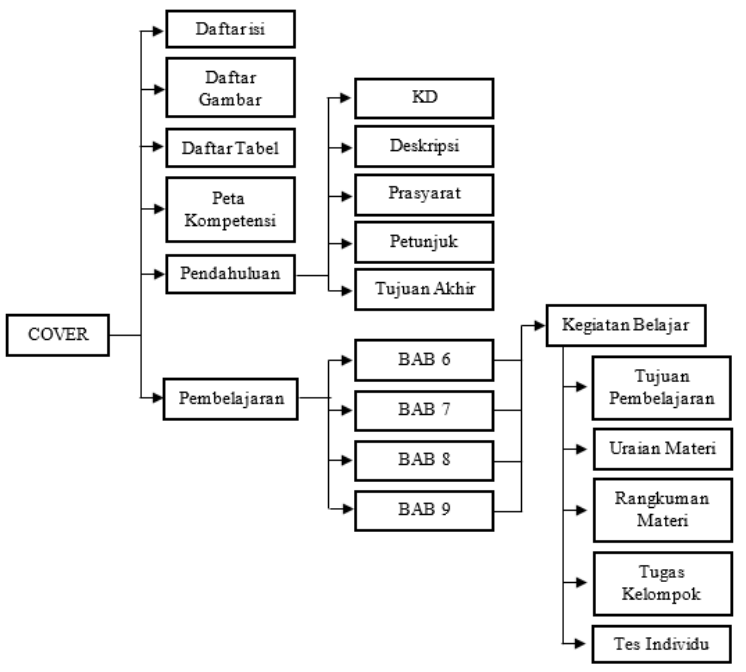

Gambar 2. Struktur Diagram Alir Bahan Ajar Sistem Komputer

\section{Pengembangan (Development)}

Tahap pengembangan ini merupakan tahapan proses pembuatan bahan ajar interaktif yang akan dikembangkan. Pada tahap ini dilakukan implementasi berdasarkan tahap sebelumnya yaitu tahap desain yang telah dirancang sesuai dengan desain materi pembelajaran dan desain antarmuka. Pada tahap pengembangan ini penyusunan bahan ajar yang mencakup penulisan dan susunan kerangka modul menggunakan teori dari (Daryanto, 2013).

Sebelum bahan ajar interaktif dibuat, harus dilakukan pengembangan materi pembelajaran yang akan dituangkan dalam bahan ajar tersebut. Bahan ajar interaktif ini akan dikembangan menggunakan software Photoshop CS6 untuk pembuatan desain cover dan icon, dan Sigil untuk pembuatan bahan ajar yang berbasis HTML, CSS dan javascript.

\section{Implementasi (Implementation)}

Tahap implementasi merupakan tahap penerapan bahan ajar yang telah dikembangkan. Sebelum bahan ajar diimplementasikan, dilakukan validasi ahi materi dan ahli media serta uji coba kepada siswa.

Jika hasil dari validasi menunjukan persentase tinggi maka bahan ajar siap untuk digunakan. Bahan ajar interaktif diimplementasikan di SMKN 1 Banyuwangi, yaitu pada siswa kelas $X$ Jurusan Rekayasa Perangkat Lunak. Tahap implementasi ini hanya sebatas dilakukan sampai proses uji coba saja, karena hanya ditujukan untuk mengetahui tingkat kelayakan bahan ajar yang digunakan. Bahan ajar ini kemudian diserahkan kepada guru matapelajaran sistem komputer untuk digunakan sebagai pendukung proses pembelajaran.

\section{Evaluasi (Evaluation)}

Evaluasi bertujuan untuk mengetahui kevalidan dan kelayakan dari bahan ajar yang telah dikembangkan. Melakukan evaluasi berdasarkan data-data yang diperoleh pada saat penelitian di lapangan. Evaluasi kevalidan produk dapat dilakukan oleh ahli materi dan ahli media. Hasil evalusi dari ahli materi dan ahli media dapat digunakan sebagai dasar untuk melakukan 


\section{TEKNO Jumal Teknologi, Eektro, dan kejivuan}

http://journal2.um.ac.id/index.php/tekno | ISSN

perbaikan terhadap bahan ajar interaktif yang telah dikembangkan. Sedangkan evaluasi kelayakan produk dapat dilakukan dengan melakukan uji coba. Hasil evaluasi secara keseluruhan dapat dijadikan sebagai dasar untuk mengukur kualitas dan fungsionalitas dari bahan ajar interaktif yang telah dikembangkan.

\section{Hasil dan Pembahasan}

Hasil produk yang telah dikembangankan adalah bahan ajar interaktif pada matapelajaran sistem komputer berbasis PBL untuk SMK. Pengembangan yang dihasilnya menerapkan langkah-langkah model pengembangan ADDIE.

Halaman pendahuluan

Halaman pendahuluan berisi tentang kompetensi dasar, deskripsi, prasyarat, petunjuk penggunaan, dan tujuan akhir. Pada pendahuluan ini terdapat dropdown untuk meringkas lima poin tersebut agar menjadi satu halaman. Setelah ada poin yang di klik seperti kompetensi dasar, maka akan terlihat seperti pada Gambar 3.

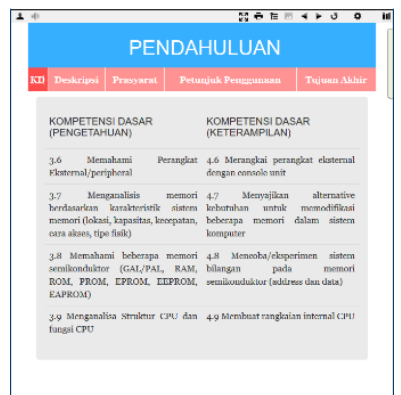

Gambar 3. Tampilan Halaman Pendahuluan

Halaman bab

Halaman bab berisi identitas bab, judul bab, beberapa kegiatan belajar, serta video terkait materi dalam bab tersebut. Kegiatan belajar dimuat dalam sebuah kotak yang dapat di klik. Ketika di klik maka akan menampilkan popup. Popup berisi tentang penjelasan singkat terkait materi yang akan dipelajari pada kegiatan belajar tersebut. Selain itu juga terdapat link menuju halaman kegiatan belajar tersebut yang ditunjukkan dengan kata "mulai belajar ". Tampilan popup dapat dilihat pada Gambar 4.

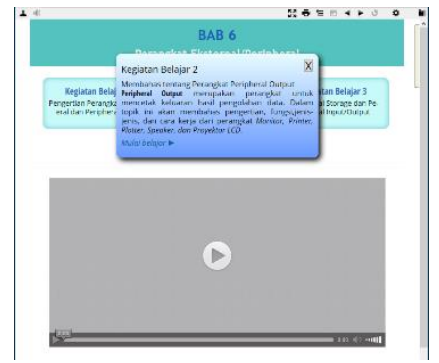

Gambar 4. Tampilan Halaman Bab

TEKNO Vol.28 Issue 2, p166-176 | Jurusan Teknik Elektro, Universitas Negeri Malang, Indonesia | September 2018 Arizia Aulia Aziiza, Syaad Patmanthara, Triyanna Widiyaningtyas | Pengembangan bahan ajar interaktif pada judul... 


\section{TEKNO Jumal Teknologi, Eektro, dan Kejivuan}

http://journal2.um.ac.id/index.php/tekno | ISSN

Halaman kegiatan belajar

Halaman kegiatan belajar berisikan materi yang akan dipelajari dalam satu kali pertemuan. Dalam setiap kegiatan belajar terdiri dari lima poin, yaitu: (1) tujuan pembelajaran, (2) uraian materi, (3) rangkuman materi, (4) tugas kelompok, dan (5) tes individu. Halaman kegiatan belajar dapat dilihat pada Gambar 5.

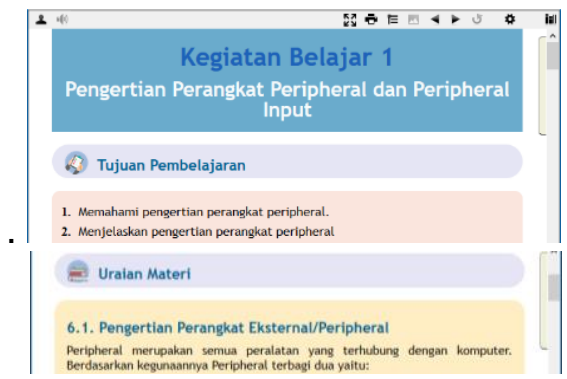

Gambar 5. Tampilan Halaman Kegiatan Belajar

Halaman input password

Halaman tes individu ini memberikan perintah untuk mengisikan password pada form yang tersedia. Untuk setiap tes individu pada kegiatan belajar memiliki password yang berbeda. Jika password yang dimasukkan benar, maka tes soal untuk tes individu dapat dikerjakan. Jika password salah, maka terdapat feedback bahwa password yang dimasukkan salah. Tampilan halaman input password pada tes individu dapat dilihat pada Gambar 6.

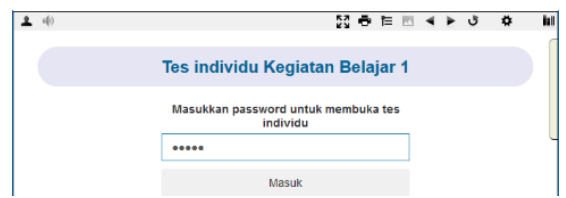

Gambar 6. Tampilan Halaman Input Password

Halaman tes individu pilihan ganda

Tes individu yang disajikan dalam bentuk pilihan ganda terdiri dari lima pilihan jawaban. Tes individu berupa pilihan ganda ini memiliki jumlah yang berbeda pada setiap kegiatan belajar menyesuaikan dengan cakupan materi pembelajaran. Ketika jawaban dipilih dapat dilihat pada Gambar 7.

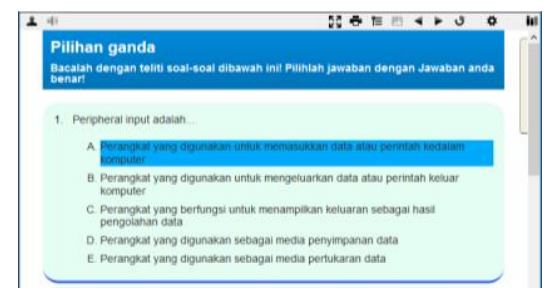

Gambar 7. Tampilan Tes Pilihan Ganda

TEKNO Vol.28 Issue 2, p166-176 | Jurusan Teknik Elektro, Universitas Negeri Malang, Indonesia | September 2018 Arizia Aulia Aziiza, Syaad Patmanthara, Triyanna Widiyaningtyas | Pengembangan bahan ajar interaktif pada judul... 


\section{TEKNO Jumal Teknologi, Eektro, dan Kejivuan}

http://journal2.um.ac.id/index.php/tekno | ISSN

Tampilan tes individu fill in the blank

Pada halaman ini terdapat form untuk mengisi jawab dan button "submit" digunakan ketika telah selesai mengisi jawaban. Seperti halnya tes individu yang sebelumnya, tes individu berupa fill in the blank ini memiliki feedback jawaban yang benar dan salah, serta jumlah jawaban benar dan salah. Tampilan tes individu fill in the blank dapat dilihat pada Gambar 8.

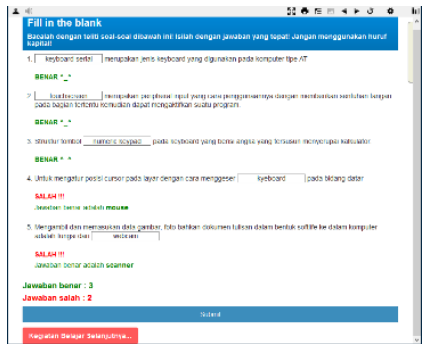

Gambar 8. Tampilan Tes Fill in the Blank

\section{Hasil Validasi Ahli Materi}

Validasi ahli materi dilakukan oleh Ibu Triyanna Widiyaningtyas, S.T., M.T. yang merupakan dosen jurusan Teknik Elektro Universitas Negeri Malang dan Bapak Melanoke Pramanik, S.Kom. yang merupakan Ketua Program Keahlian Rekayasa Perangkat Lunak SMK Negeri 1 Banyuwangi. Instrumen angket yang digunakan untuk validasi ahli materi ini menggunakan angket dengan 40 butir pernyataan yang dikembangkan dengan mengunakan kisi-kisi dari (Daryanto, 2013).

Melalui hasil validasi ahli materi dari dua ahli menghasilkan rata-rata validasi materi dengan persentase sebesar $91,2 \%$ yang menunjukkan bahwa bahan ajar interaktif berupa buku digital pada matapelajaran sistem komputer kelas X semester 2 dikatakan valid, dan dapat digunakan tanpa revisi. Hal ini didukung dengan penelitian (Adhim, 2015).

Sedangkan data kualitatif dari review ahli materi antara lain: (1) format penulisan evaluasi, (2) konsistensi format penulisan keterangan gambar, (3) mengganti gambar yang kurang jelas, dan (4) Perbaiki kesalahan penulisan kalimat dan pencetakan huruf miring untuk kata asing maupun kata serapan.

Perbaikan yang sudah dilakukan oleh peneliti adalah sebagai berikut: (1) format penulisan evaluasi sudah diberi titik sebanyak tiga di setiap akhir soal, (2) format tulisan keterangan gambar sudah dibuat konsisten dengan awalan huruf besar disetiap kata, (3) perbaikan gambar yang kurang jelas, dapat dilihat pada Gambar 9.

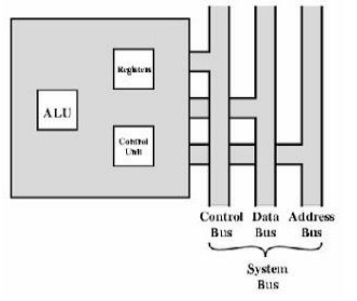

(a)

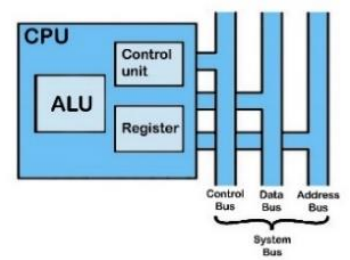

(b)

Gambar 9. (a) Tampilan Gambar Sebelum Direvisi, dan (b) Tampilan Gambar Setelah Direvisi

TEKNO Vol.28 Issue 2, p166-176 | Jurusan Teknik Elektro, Universitas Negeri Malang, Indonesia | September 2018 Arizia Aulia Aziiza, Syaad Patmanthara, Triyanna Widiyaningtyas | Pengembangan bahan ajar interaktif pada judul... 


\section{TEKNO Jumal Teknologi, Eektro, dan Kejivuan}

http://journal2.um.ac.id/index.php/tekno | ISSN

\section{Hasil Validasi Ahli Media}

Validasi ahli media dilakukan oleh Ibu Dila Umnia Soraya, S.Pd., M.Pd.. yang merupakan dosen Jurusan Teknik Elektro Universitas Negeri Malang. Instrumen angket yang digunakan untuk validasi ahli materi ini menggunakan angket dengan 52 butir pernyataan yang dikembangkan dengan mengkombinasikan kisi-kisi (Daryanto, 2013) dan kisi-kisi (Leacock et al, 007).

Melalui hasil validasi ahli media menghasilkan persentase sebesar $86.05 \%$ yang menunjukkan bahwa bahan ajar interaktif berupa buku digital pada matapelajaran sistem komputer kelas $X$ semester 2 dikatakan sangat valid, dapat digunakan tanpa revisi dan dapat diujicobakan kepada siswa. Hal ini didukung dengan penelitian Sritama (2016).

Sedangkan data kualitatif dari review ahli media antara lain: (1) jenis dan ukuran huruf disamakan, (2) kata penting pada glosarium dibuat tebal dan miring, (3) ukuran icon disesuaikan dengan kata disebelahnya, dan (4) input password disimbolkan.

Perbaikan yang sudah dilakukan oleh peneliti adalah sebagai berikut: (1) ukuran huruf dibah dengan Trebuchet MS dengan ukuran 12px, (2) kata penting pada glosarium sudah di cetak miring dan tebal, (3) ukuran icon sudah disesuiakan dengan menggunakan ukuran text dengan pixel, dan (4) hidden untuk password. Perbaikan yang sudah dilakukan adalah sebagai berikut.

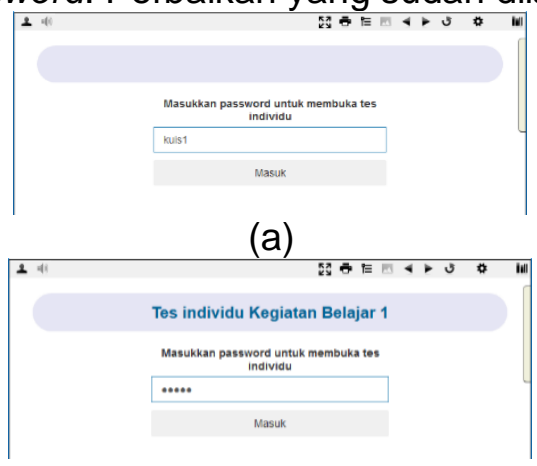

(b)

Gambar 10. (a) Tampilan Password Sebelum Direvisi, dan (b) Tampilan Password Setelah Direvisi

\section{Hasil Uji Coba Perseorangan}

Uji coba perseorangan dilakukan dengan memberikan angket kepada tiga siswa yang diambil dari kelas X RPL 2 secara acak. Instrumen uji coba perseorangan terdiri dari 16 butir pernyataan yang dikembangkan dengan mengkombinasikan kisi-kisi (Daryanto, 2013) dan kisi-kisi (Leacock et al,2007).

Melalui hasil uji coba perseorangan dari tiga siswa menghasilkan rata-rata persentase sebesar $77.08 \%$ yang menunjukkan bahwa bahan ajar interaktif berupa buku digital pada matapelajaran sistem komputer kelas $\mathrm{X}$ semester 2 dikatakan cukup layak, dapat digunakan dengan revisi (Mardiyanto, 2016).

Perbaikan yang sudah dilakukan oleh peneliti adalah sebagai berikut: (1) tulisan tes individu yang semua berjalan dari kiri ke nakan, dibuat diam agar mudah dibaca, (2) mengganti background Gambar putih menjadi transparan seperti yang terlihat pada Gambar 11.

TEKNO Vol.28 Issue 2, p166-176 | Jurusan Teknik Elektro, Universitas Negeri Malang, Indonesia | September 2018

Arizia Aulia Aziiza, Syaad Patmanthara, Triyanna Widiyaningtyas | Pengembangan bahan ajar interaktif pada judul... 


\section{TEKNO Jumal Teknologi, Eektro, dan Kejivuan}

http://journal2.um.ac.id/index.php/tekno | ISSN

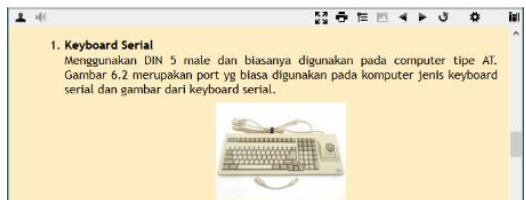

(a)

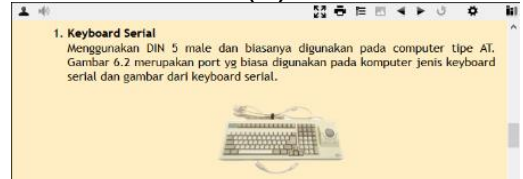

(b)

Gambar 11. (a) Tampilan Background Gambar Sebelum Direvisi, dan (b) Tampilan Background Gambar Setelah Direvisi

\section{Hasil Uji Coba Kelompok Kecil}

Uji coba perseorangan dilakukan dengan memberikan angket kepada 18 siswa yang diambil dari kelas X RPL 2 secara acak. Instrumen uji coba kelompok kecil terdiri dari 16 butir pernyataan yang dikembangkan dengan mengkombinasikan kisi-kisi (Daryanto, 2013) dan kisi-kisi (Leacock et al, 2007).

Melalui hasil uji coba kelompok kecil dari 18 siswa menghasilkan rata-rata persentase sebesar $81.1 \%$ yang menunjukkan bahwa bahan ajar interaktif berupa buku digital pada matapelajaran sistem komputer kelas $X$ semester 2 dikatakan cukup layak, dapat digunakan dengan revisi. Hal ini didukung dengan penelitian (Ardianto, 2016).

Perbaikan yang dilakukan antara lain (1) perbaikan tulisan kata, dan (2) memperbaiki tampilan halaman bab agar lebih selaras, seperti pada Gambar 12.

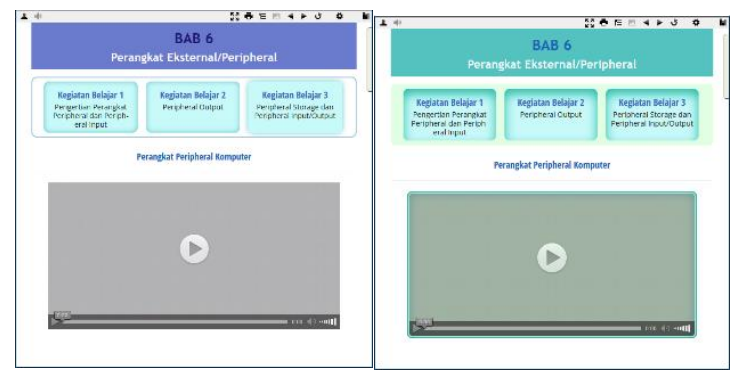

(a)

(b)

Gambar 12. (a) Tampilan Bab Sebelum Direvisi, dan (b) Tampilan Bab Setelah Direvisi.

\section{Hasil Uji Coba Kelompok Besar}

Uji coba kelompok besar dilakukan dengan memberikan angket kepada seluruh siswa kelas $\mathrm{X}$ RPL 1 yang berjumlah 34 siswa. Instrumen uji coba kelompok besar terdiri dari 16 butir pernyataan yang dikembangkan dengan mengkombinasikan kisi-kisi (Daryanto, 2013) dan kisikisi (Leacock et al, 2007). 


\section{TEKNO Jurnal Teknologi, Elektro, dan Kejuruan}

http://journal2.um.ac.id/index.php/tekno | ISSN

Melalui hasil uji coba kelompok besar dari 34 siswa menghasilkan rata-rata persentase sebesar $88.3 \%$ yang menunjukkan bahwa bahan ajar interaktif berupa buku digital pada matapelajaran sistem komputer kelas $\mathrm{X}$ semester 2 dikatakan sangat layak, dan dapat digunakan tanpa revisi. Hal ini didukung dengan penelitian (Stritama, 2016).

\section{Kesimpulan Dan Saran}

\section{Kesimpulan}

Produk hasil pengembangan yang telah direvisi adalah bahan ajar interaktif berupa buku digital dengan format (.epub) pada matapelajaran sistem komputer berbasis PBL untuk siswa kelas X semester 2 di SMK Negeri 1 Banyuwangi.

Bahan ajar interaktif berupa buku digital ini dirancang sesuai dengan karakteristik dan kebutuhan siswa kelas X Program Keahlian Rekayasa Perangkat Lunak di SMK Negeri 1 Banyuwangi. Materi dalam bahan ajar disesuaikan dengan silabus dan KI KD Kurikulum 2013 revisi.

Bahan ajar interaktif berupa buku digital ini dikembangkan dengan menggunakan model pengembangan ADDIE. Sebelum bahan ajar diimplementasikan, langkah yang harus dilakukan adalah melakukan validasi ahli materi dan ahli media.

Bahan ajar interaktif berupa buku digital ini dilakukan uji coba untuk mengetahui kelayakan produk yang dikembangkan. Uji coba dilakukan melalui tiga tahap, yaitu uji coba perserorangan, uji coba kelompok kecil, dan uji coba kelompok besar Setelah ketiga tahap uji coba dilakukan, maka akan diperoleh hasil yang menyatakan bahwa bahan ajar yang dikembangkan dikatakan layak dan dapat digunakan oleh siswa untuk menunjang kegiatan pembelajaran.

\section{Saran}

Bahan ajar interaktif berupa buku digital dapat digunakan secara optimal oleh guru dan siswa sebagai sumplemen pembelajaran.

Bahan ajar interaktif berupa buku digital pada matapelajaran sistem komputer berbasis PBL ini tidak hanya dapat diterapkan pada Program Keahlian RPL saja, namun dapat diterapkan di Program Keahlian Multimedia dan TKJ. Bahan ajar ini juga dapat digunakan oleh sekolah lain, namun harus memperhatikan karakteristik siswa dan sarana yang digunakan sesuai atau tidak dengan bahan ajar interaktif berupa buku digital ini.

Berdasarkan hasil dari bahan ajar yang telah dikembangkan, terdapat beberapa saran yang diharapkan dapat menyempurnakan bahan ajar ini, yaitu (1) penambahan simulasi tentang merakit komputer, (2) penambahkan materi sistem komputer selama dua semester, (3) dapat digunakan pada Smartphone dengan ukuran file yang tidak terlalu besar, dan (4) menambahkan jenis soal yang bervariasi.

\section{Daftar Rujukan}

Adhim, Fauzul. 2016. Pengembangan Media Pembelajaran Berbasis Tutorial Pada Mata Pelajaran Sistem Komputer untuk Meningkatkan Hasil Belajar Siswa di SMK Negeri 1 Pungging. Skripsi tidak diterbitkan: Universitas Negeri Malang.

TEKNO Vol.28 Issue 2, p166-176 | Jurusan Teknik Elektro, Universitas Negeri Malang, Indonesia | September 2018 Arizia Aulia Aziiza, Syaad Patmanthara, Triyanna Widiyaningtyas | Pengembangan bahan ajar interaktif pada judul... 


\section{TEKNO Jumal Teknologi, Eektro, dan Kejivuan}

http://journal2.um.ac.id/index.php/tekno | ISSN

Ardianto, Tomi. 2016. Pengembangan Modul Digital Berbasis EPUB Pada Mata Pelajaran Rancang Bangun JaringanKelas XI TKJ Di SMK Negeri 2 Malang. Skripsi tidak diterbitkan: Universitas Negeri Malang.

Branch, Robert Maribe. 2009. Instructional Design: The ADDIE Approach. USA: Departement od Educational Physiology and Instructional Technology University of Georgia.

Daryanto. 2013. Menyusun Modul Bahan Ajar untuk Persiapan Guru dalam Mengajar. Yogyakarta: Gava Media.

Daryanto. 2014. Pendekatan Pembelajaran Saintifik Kurikulum 2013. Yogyakarta: PT. Gava Media.

Leacock, Tracey L., and Nesbit, John C. 2007. A Framework for Evaluating the Quality of Multimedia Learning Resources. Jurnal Educational Technology \& Society, 10(2), 44-59.

Tasri, Lu'mu. 2011. Pengembangan Bahan Ajar Berbasis Web. Jurnal MEDTEK, 3(2): 1-8, (Online), (http://www.ft-unm.net/), diakses 22 Mei 2016.

Mardiyanto, Sigit. 2016. Pengembangan Media Pembelajaran Buku Digital Interaktif Berbasis Adobe Flash CS3 Pada Mata Pelajaran Perakitan Komputer di SMK Muhammadiyah 2 Moyudan. Jurnal Pendidikan Teknik Informatika Universitas Negeri Yogyakarta (online), (http://journal.student.uny.ac.id), diakses 18 Mei 2017.

Patmanthara, Syaad. 2015. Pembelajaran Berbantuan Komputer. Jember: Penerbit Cerdas Ulet Kreatif.

Prihantana, M. A. S., Santyasa, I. W. \& Warpala, I. W. S. 2014. Pengembangan Bahan Ajar Interaktif berbasis Pendidikan Karakter Pada Matapelajaran Animasi Stop Motion untuk Siswa SMK. E-Journal Program Pascasarjana Universitas Pendidikan Ganesha, Vol 4: 1-12.

Stritama, Reti Avitananda.2016. Pengembangan Media Pembelajaran Berbasis Multimedia Interaktif Matapelajaran Sistem Operasi Semester Ganjil Kelas X Program Keahlian Teknik Komputer Jaringan di SMK Islam Batu. Skripsi tidak diterbitkan: Universitas Negeri Malang.

Sukmadinata, N. S. 2015. Metode Penelitian Pendidikan. Bandung: Penerbit Remaja Rosdakarya Offset.

TEKNO Vol.28 Issue 2, p166-176 | Jurusan Teknik Elektro, Universitas Negeri Malang, Indonesia | September 2018 Arizia Aulia Aziiza, Syaad Patmanthara, Triyanna Widiyaningtyas | Pengembangan bahan ajar interaktif pada judul... 